This is the pre-peer reviewed version of the following article which has been published in final form as follows:

Martin, D.F. 2015. 'Does Native Title merely provide an entitlement to be native? Indigenes, identities, and

applied anthropological practice', The Australian Journal of Anthropology 26(1), pp 112-127.

\title{
Does Native Title merely provide an entitlement to be native? Indigenes, identities, and applied anthropological practice
}

\author{
Anthropos Consulting \\ The Australian National University
}

david.martin@anthropos.com.au

\begin{abstract}
This paper is directed to two immediate purposes which lie beyond anthropology as practiced within academia: to contribute to the ongoing dialogue within the discipline on applied anthropological engagement in and with the Australian native title and Indigenous development arenas; and secondly to add to our conversations with Indigenous people themselves on what it means to be Indigenous in contemporary Australia. It aims to do this by focusing initially on what I argue are two ostensibly alternative constructions of contemporary Indigenous identities implicitly established through different provisions of Australia's Native Title Act, one of which I propose draws from the particular legal construction of Indigenous tradition in that Act and in native title jurisprudence, and the other from certain aspects of identity held to be associated with modernity. I argue however that there is a false dichotomy between tradition and modernity in contemporary circumstances, and that Indigenous identities are better understood as 'hybrid' in the sense that they involve a complex interpenetration of forms of identity and practice drawn from diverse domains. I further argue that these arguments have important implications for an applied anthropological practice well beyond the native title arena, and for Indigenous people themselves.
\end{abstract} Keywords: Indigenous identities, hybridity, traditionalism, Native title, applied anthropology 
To make its aims clear from the start, this paper is directed to two immediate purposes which lie beyond anthropology as practiced within academia: To contribute firstly to the ongoing dialogue within the discipline on applied anthropological engagement in and with the Australian native title and Indigenous development arenas; and secondly to add to our conversations with Indigenous people themselves on what it means to be Indigenous in contemporary Australia. ${ }^{1}$ These matters of course involve a complex intellectual, political and ethical terrain with direct impacts on Indigenous people's lives. Analytical treatment of concepts such as 'modernity' and 'tradition' reflects such complexity, and has a long history of critical scholarly attention (e.g. in more recent times Hobsbawm and Ranger 1983; Goody 2004). It is not my purpose here to develop a theoretical exegesis of these concepts based on this extensive literature. Rather, and given my particular applied purposes, I take up the proposal by Rosaldo (1995: xvi) that the analytical use of the terms 'tradition' and 'modernity' requires a prior examination of their vernacular deployment and critical assessment before they are of utility in social analysis (and thus, I would suggest, in an anthropology directed to applied ends). The 'vernacular' usages of tradition and modernity that I examine are in the case of tradition explicitly through Australia's Native Title Act (NTA) and native title jurisprudence associated with proving native title, and in the case of modernity implicitly in other provisions of that Act as well as in Australian public Indigenous affairs policy discourse promulgated by certain influential conservative commentators.

\section{Eddie Koiki Mabo, tradition, and modernity}

The Mabo decision overturned the doctrine of terra nullius under which Australia was held to have been a land without owners until sovereignty was claimed in 1788 by Governor Phillip for the British Crown, and which led to the passage in 1993 of the Native Title Act (Cth) (NTA). Native title has now been recognised over more than $15 \%$ of the Australian land mass (National Native Title Tribunal 2012), albeit mostly coexisting with the rights granted to landholders under the titles issued by State and Territory governments. Over 500 Indigenous Land Use Agreements (although with widely varying significance and scale) have been registered nationally between Indigenous groups and resource developers, governments and others. Despite the very limited character of the rights and interests that can be recognised as native title and the 
problematic directions which Australian native title jurisprudence has taken (Ritter 2009; Strelein 2009), such outcomes arguably represent something of a sea change in the acceptance of a legitimate place for Indigenous people at the table in so many negotiations over land and resource use, and there is much to celebrate. There is, of course, also much to be critical of - not least the inordinately complex, expensive, and for Indigenous people alienating processes through which native title is legally recognised (e.g. Aboriginal and Torres Strait Islander Social Justice Commissioner 2011: 75-106).

There have been significant human costs borne by the native title claimants themselves. Demonstrating to the satisfaction of governments and the Court that their native title continues to exist is arduous, stressful, confronting — and often confrontational — and for some a cause of bitterness and protest. There is also the extensive time taken to resolve most claims (whether by litigation or mediation), which means that all too often senior Indigenous people whose evidence is crucial to successful determinations have died before they themselves could celebrate the recognition of their native title, tragedies which reflect the far shorter lifespans of so many Indigenous Australians. Indeed, Eddie Koiki Mabo himself died just a few months before the High Court decision in the case in which he had played such a pivotal initiating role.

Eddie Mabo's importance to native title in my view however, lies beyond the High Court decision itself. His biography (Loos and Mabo 1996: 3-22; Mabo n.d.) illustrates an important truth sometimes lost sight of in the complex legally-driven manoeuvring around proving native title. He was a man who developed a passionate conviction that Australian law should recognise that his family's land on the island of Mer did not belong to the Crown, but was theirs under his people's own laws. Nevertheless, he was also a man who played an active political role in advocating more broadly for social justice, and who worked on a range of occupations in various north Queensland industries. He left Mer as a teenager to work on pearling boats in the Torres Straits, and when unable to return home because the community council of the day would not allow him to return, he moved to Townsville. There, he worked in occupations such as cane cutting and (like many other Torres Strait Islanders) as a fettler on the railways. He was to become a union representative on the construction of the Townsville to Mount Isa railway line, and subsequently worked for the Townsville Harbour Board. Significantly 
for the history of native title in Australia, after he left the Harbour Board following persecution for his political views, Eddie Mabo took up work as a gardener at James Cook University in Townsville. Amongst other things, this led to his meeting historian Henry Reynolds (who in the course of numerous conversations informed him that under Australian law the Crown and not his family owned what he considered to be their land on Mer), and to attending a land rights conference in 1981 which ultimately, over the subsequent decade, led to the lodging and final success of the High Court case.

What I wish to draw from this highly abbreviated sketch of elements of a complex life history, is that Eddie Mabo was both a man with a strong commitment to his own people's traditions, and a thoroughly integrated participant in the contemporary social, political and economic life of the north Queensland region to which he had moved. His life, in my view, suggests that forms of tradition and modernity are not incompatible, but are interrelated aspects of something rather more complex. This is far from a novel proposition (e.g. Hobsbawm and Ranger 1983; Goody 2004; Sahlins 1999b; Rosaldo 1995), but this paper aims to examine implications of that interrelationship for the particular purposes outlined at the beginning of this paper.

\section{Statutory and political constructions of modernity and tradition}

In this section, following Rosaldo's suggestion discussed earlier, I sketch in constructions of tradition and modernity in particular public arenas - in the case of tradition in the provisions of the NTA concerned with the proof of native title, and in that of modernity implicitly in other provisions of that Act as well as in contemporary public Indigenous affairs policy and discourse.

\section{Tradition in the Native Title Act}

The first construction of Indigenous identity arises out of a conjunction between the findings of the 1992 Mabo decision in the Australian High Court and certain provisions of the NTA relating to claiming native title and associated jurisprudence, while the second arises from the agreement-making provisions of the NTA. In essence, for their native title to be recognised by Australian law, Indigenous people are required to demonstrate that there has been continuity since sovereignty in what the NTA refers to in section 223 as their 'laws and customs': that is, it is required that these laws and 
customs are 'traditional' in accordance with the narrow construction of this concept in native title jurisprudence (Martin et al 2011). While native title law does encompass the possibility of changes in laws and customs, these must be shown to have arisen from adaptation to, but not fundamental transformations caused by, the historical processes of and following colonisation. Native title law also requires that the Indigenous group concerned demonstrate that it and its forebears have continued since sovereignty to practice and observe those laws and customs from which (native title law holds) their native title rights and interests derive (Martin et al 2011).

Furthermore, it is necessary to demonstrate not only that these laws and customs have been substantially maintained, but also that the particular Indigenous society itself has continued to exist since sovereignty. Indeed, the laws and customs by which the group or society is defined, structured, and reproduced through time, must themselves be shown to be 'traditional'. From this perspective, native title claims can be seen as constituting a state-resourced and mandated project of 'traditionalism' — understood (Merlan 1998: 231) as the reconstruction of an idealised representation of the relevant Indigenous people as they supposedly are, in terms of how they supposedly were in the pre-colonial past (Martin et al 2011).

The traditionalist — and essentialised — recognition of native title, and thereby of the Indigenous group or society who hold that title, is also reflected in the legal construction of the identities of those associated with that group. There is an intimate connection in native title law - a mutual entailment - between the identity of the group, the selfidentification of individuals with that group, and the acceptance of that identification by the group in accordance with its own laws and custom (such as those relating to 'descent' from relevant ancestors). In part, it is true, this construction of individual identity as derived from and authorised through norms and values which are those of the group reflect, in a reductionist form, certain commonly found elements of the principles of Indigenous landed group formation (e.g. Sutton 2003: 54-65). However, my purpose here is not to establish the cultural logics for the establishment of Indigenous identities. Rather, it is to propose that regardless of the fact that in various ways and to varying degrees, the contemporary lives of native title claimants involve multiple forms of engagement with the wider society (personal and social, professional, economic and so forth), their identities as Indigenous people - as well as that of the group - must be 
constructed for the purposes of claiming native title in a singular and traditionalist modality. Native title, one might say, merely entitles people to be native (Martin et al. 2011: 4).

Weiner (2011) has made congruent observations, in arguing that the powers, rights and interests granted to native title groups under other statutory schemes, like those in the limited forms of co-management offered through such schemes as the Wet Tropics Management Authority and the Great Barrier Reef Marine Park Authority in Queensland, can be incommensurate with interpretations under native title law of 'traditional law and custom' and 'rights and interests'. He argues that the consequence may entail legally contradictory versions of Aboriginal agency. While I will return to Weiner's arguments, my purpose here is rather different from his; my concern here is not with legal (and thus political) issues and inconsistencies in the rights and interests which may arise under different legal schemes, but rather with the nature of Indigenous identity that these schemes implicitly entail, and indeed may have a role in establishing.

\section{Modernity in the Native Title Act}

I have argued that demonstrating native title requires Indigenous people (as individuals, and as groups) to portray their identities in a traditionalist form. Yet there are other provisions in the NTA which provide at least the possibility for Indigenous people to negotiate their identities and futures relatively free of the strictures of traditionalism. These do not arise out of the findings of the original Mabo High Court decision itself, but under the agreement-making provisions of the NTA originally negotiated by Indigenous interests, and subsequently substantially supplemented in the 1998 'Ten Point Plan' amendments to that Act. Indigenous Land Use Agreements (ILUAs), a particular form of contract established under section 24 of the NTA, are intended "to facilitate the negotiation of voluntary but binding agreements as an alternative to more formal native title machinery" (Commonwealth of Australia 1997: 22; see Smith 1998). ILUAs offer possibilities for claimants to negotiate ways to have their interests and certain of their rights recognised and aspirations met (including for development), without having to jump the legal hurdle of demonstrating that they (people, cultures, rights and interests, or aspirations) are 'traditional' as native title law constructs it 
(Martin et al. 2011). Robins (2003:277) has provided a parallel and very insightful account of a similar pre- and post-land claim dichotomy in post-apartheid South Africa. While ILUAs are established through processes of interest based negotiations, the character and source of those interests are not prescribed by native title law, unlike native title rights and interests. ILUAs are relatively unfettered in terms of their subject matter, and can deal with such matters as obtaining legal title to particular lands, employment, business development, education and training, and financial benefits as well as cultural heritage protection and environmental management (Smith 1998; National Native Title Tribunal n.d.). Governments also typically use them as a mechanism for resolving native title claims without the necessity of litigating, and resource developers to provide certainty of access for exploration and mining. ILUAs have become an important component in the broader native title arena, not only in the practical implementation of determinations of native title, but also in offering mechanisms through which Indigenous people can negotiate on a broad range of matters. Typically these matters involve varying degrees of incommensurability and translation between Indigenous worldviews and aspirations and the terms of the agreements (Martin 2009). Nonetheless, they can go well beyond the limited legal construction of native title established by the conjunction between the principles of the Mabo High Court decision, subsequent case law, and the provisions of the NTA. What is significant for my argument here is that while ILUAs are negotiated for the group itself, potentially binding not only its current members but also their descendants (Godden and Dorsett 1999: 4), many — although not all — of the benefits and possibilities arising from these agreements are realised essentially at the individual, not the group, level (Martin 2009). I have in mind here typical provisions around such matters as education as well as skill-specific training, employment, and business development in particular. These matters, of course, have long been at the heart of Australian government policies in Indigenous affairs. It is true that the provisions of ILUAs, unlike the parameters of welfare reform, are negotiated by or on behalf of Indigenous people themselves, and offer possibilities and options rather than establishing mandatory compliance with legally or administratively defined criteria. Nonetheless they are arguably also a part of the broad repertoire of social technologies which are directed to facilitating the move for the Indigenous people concerned to a 
more individuated and 'modernist' identity, at least for those who opt to take advantage of these measures (Martin et al. 2011).

Modernity, as I have noted, is a descriptor for a set of complex phenomena with a very long history. However, for the purposes of my discussion here the term can usefully serve as a proxy for an essentialised set of values and practices supposedly held by those in mainstream Australian society in particular and the West more generally, towards which Indigenous affairs policies should (it is argued) aim to transition Indigenous people. That is, from such a position 'modernity' can be read as standing for the habitus which an assimilated individual of Indigenous descent would and should assume, in order to become a full participant in the contemporary Australian economy and thus society. Such views can be seen most explicitly in the Australian context in the writings of conservative commentators such as Hughes (2005, 2007; see also Hughes and Warin 2005), and Johns (2007, 2008, 2012), whom I have elsewhere described as proposing a form of policy 'alchemy' whereby Indigenous individuals are to be transmuted from their debased commitment to communalism and social dysfunction to the gold of autonomous economic actors (Martin 2011a; see also Dalley and R. Martin, this volume).

However, this ultimate policy goal for Indigenous people is not only the aim of political conservatives, but has become incorporated into the dominant paradigm in Australian Indigenous affairs under governments of all political persuasions over the past few decades. Central to this paradigm is the utilisation of market mechanisms as the assumed drivers of personal and social as well as economic transformations, an assumption which forms a component of what has been called 'economic neoliberalism' (Hay 2004: 507-8). As has been argued elsewhere for the Australian context (e.g. Altman and Hinkson 2010; Martin 2001, 2011a), such policies have the consequence, increasingly intended by governments, of morally reforming Indigenous individuals through engagement with the market economy. Here;

... work is not just about production, or indeed about wages, but about making one's way in the world as an independent and self-sufficient actor. Through work, one thereby discharges one's obligations to society in general but in a manner abstracted from commitments to particular networks and communities and to particular locales (Martin 2011a: 209). 
This is an archetypical modernist project, with its emphasis on a particular form of individualism and its assumption that the only appropriate trajectory for Indigenous people entails economic assimilation, largely through the provision of labour in the general Australian economy. For those living in many rural and remote regions this would necessarily require very significant out-migration to regions where work is (supposedly) available (Taylor 2009). In my view, it is important that anthropologists develop critiques of such ideologically driven and simplistic approaches to the complex issues posed by the situations of Australian Indigenous people (e.g. see that of Altman and Hinkson 2010). But it is also necessary to give critical attention to the central issue of how Indigenous people (especially in remote regions) are to gain livelihoods (Austin Broos 2011), and to what that may entail for the nature of Indigenous people's engagements with modernity.

Certainly, it is possible to broaden this narrow and ideological view of development possibilities for remote-dwelling Indigenous people to encompass a diverse range of productive livelihoods on and off the 'Indigenous estate' (Altman 2001, 2005, 2009; Altman, Buchanan and Larsen 2007), which do not necessarily entail the enforced mobility of Indigenous people and their economic, social and cultural assimilation into the general Australian society. Such livelihoods have the potential for Indigenous people to maintain distinctive sets of connections to kin and country in ways which challenge this assimilatory project. Nonetheless, these connections cannot be seen as located within self-defining, self-reproducing and bounded Indigenous lifeworlds. Even in the most remote of locales, Indigenous people's systems of connections, meanings, values and practices - and thus identities - are variously produced and reproduced, transmitted and transformed through processes involving engagement with forms whose origins lie in the wider society, and ultimately globally (Martin 2003, Sahlins 1999a: 410-11). As Rosaldo (1995: xvi) put it, “our global contemporaries all equally inhabit a late-twentieth-century world."

Thus, it is transformation, not stasis, which lies and will continue to lie at the heart of postcolonial Indigenous experience. In terms of the central concerns of this paper regarding anthropological praxis in the native title and Indigenous development arenas, does this mean that there has been since colonisation and will continue to be for Indigenous people inevitable trajectories (albeit varying by geography, history and other 
factors) from tradition to a singular modernity, of the form implicit in the habitus of the assimilated Indigenous individual discussed above? This question, of significant import to applied anthropological practice is the focus of the following section.

\section{Tradition, modernity, hybridity}

I argued earlier that the process which Australian law mandates for the recognition of native title is a traditionalist and essentialising one, and that this is also reflected in the implicit legal construction of the identities of Indigenous claimants. I also proposed however that the agreement-making provisions of the NTA were not prescriptive in this regard, but provided mechanisms by which Indigenous people could seek to further their broader and diverse aspirations, including those relating to matters which are typically associated with modernity. Australian native title law is not based on any coherent theory of a relationship between tradition and modernity; indeed, there is arguably a quite fundamental disjunction manifested in the provisions of the Act for claims and those for agreements respectively, which were established in the political processes through which the original NTA and the subsequent 'Ten Point Plan' amendments were negotiated (Ritter 2009). The very transformations in Indigenous people's lives which are the raison d'etre for the agreement-making provisions of the NTA simultaneously have the potential to transform what the law construes as their 'traditional laws and customs' and thereby render their native title vulnerable to subsequent legal challenge (e.g. by a hostile State government).

Certainly, as outlined previously the assumption of proponents of economic neoliberalism in Australian Indigenous affairs such as Hughes and Johns is that there is a unilineal trajectory from an adherence to (debased and dysfunctional) tradition to a particular - and indeed prescribed - form of modernity. The former has to be abandoned by the individuals concerned, in order that they may embrace the latter (Martin 2011a). However, that modernity can be understood as being of a singular form, and that there is necessarily a tradition-modernity dichotomy, have long been problematized (see Kowal, this volume). An influential challenge to the sometimes triumphalist assertions that modernisation necessarily entails homogenisation and the convergence of the societies undergoing it towards particular western values and institutional forms, is posed by the concept of 'multiple modernities'. Proponents of this paradigm emphasise the diversity of modern societies, each influenced by specific sets of traditions, cultural 
values, and historical trajectories (e.g. Eisenstadt 2000, Sachsenmaier et al. 2002).

Schmidt (2006: 79-81) however argues that authors working within this paradigm, such as Eisenstadt, over-emphasise what are portrayed as fundamental cultural and institutional differences across contemporary societies despite modernisation. Schmidt is critical of this, arguing that the paradigm's typical focus on cultural and institutional factors may overstate civilizational or societal differences, and that its premises imply that the variation across contemporary civilizations or social entities must be more significant than what may be held in common through the shared 'revolutionary process' involved in the breakthrough to modernity.

Nonetheless, whatever the validity of such critiques of the 'multiple modernities' paradigm when applied to contemporary civilizations or larger socio-geographic entities - e.g. as in speaking of 'African modernities' (Comaroff and Comaroff 1997, Deutsch et al 2002) - the different historical trajectories, locational, political and economic circumstances, and consequent variations in the nature of engagements of Indigenous people within settler societies such as Australia, would seem to provide a fertile ground for examining their varied responses to modernity. This is a question to which Sahlins (1999a) in his typically forthright manner directed his attention in arguing that Indigenous peoples are not necessarily resisting the technologies and conveniences of modernization or even (he proposes) the capitalist relations required to acquire them (but see e.g. Bird-David 1992; Folds 2001; Martin 2011a). Rather, he argues, they are seeking "their own cultural space in the global scheme of things" (op. cit.: 410-11) - the 'indigenization of modernity’ (Sahlins 1999b: ix-x) which as Hannerz (2002: 53) suggests is simultaneously the modernization of indigeneity. Robins (2003), drawing on case studies of Indigenous land claims in post-apartheid South Africa, argues that the various groups concerned utilise hybrid, selective, and contextual 'strategic engagements' with the state and its development interventions (see also Martin 2003), which he sees as constitutive of hybridised Indigenous identities rather than simply the acceptance or rejection of modernity and development as such. These 'indigenous modernities' arise in the complex interpenetrations of the local with wider processes, and challenge the essentialist construction of a dichotomy between tradition and modernity (Robins op. cit.: 266; Rosaldo 1995: xiv-xv), which Rosaldo observes are empirically difficult to separate in any event. 
It is necessary for my purposes to give brief attention to the notion of 'hybridity' being deployed here by Robins. Vásquez and Marquardt (2003: 58-9; see also Gutiérrez et al 1999: 288) observe that the term 'hybridity' is a useful concept in the analysis of the "multiple, fluid and often contradictory" identities and practices which have proliferated with globalization, and that its use is cross-disciplinary, as opposed to terms such as 'syncretism' (used in religious studies) and 'bricolage' (in structuralist anthropology). However, as Vásquez and Marquardt observe, following Rosaldo (1995: xv), a problem is that the term 'hybridity' as used in the biological sciences denotes the admixture between two discrete species, rather than the complex interpenetrations of which Robins and other authors write. It was this quasi-biological notion of hybridity which underlay my own concerns about Altman's (2001) description of Indigenous 'hybrid economies', understood as being comprised of overlapping traditional, market, and government subvention sectors, when I argued (Martin 2003: 3):

... while the notion of hybridity does suggest the production of new practices and values from heterogeneous sources, it does not encompass the dynamism of the new forms. Nor does it capture the recursive manner in which they both are transformations of other practices and values (and not just those originating in some 'Indigenous domain'), and in turn transform them.

However, it is precisely these recursive and interpenetrating characteristics which inform conceptions of hybridity as utilised by analysts such as Sahlins, Rosaldo and Robins, and which offer particular insights in understanding contemporary Indigenous identities in a globalizing world. Sahlins observes, following Friedman (1999), that hybridity is a genealogy not a structure, "an analytic construal of a people's history, not an ethnographic description of their way of life" (1999a: 412). Indeed, Rosaldo proposes that hybridity can be understood as "the ongoing condition of all human cultures, which contain no zones of purity because they undergo continuous processes of transculturation (two-way borrowing and lending between cultures)" (1995: xv). It is not only Indigenous identities which should not be essentialised therefore, but modernist identities themselves.

Cape York Aboriginal intellectual and political activist Noel Pearson (2006), drawing on his own life history, and the writings of Amartya Sen (2006) amongst others, also challenges essentialised understandings of identity (Indigenous and otherwise) that assume the only possibility is one of a singular affiliation of the individual or the group, 
in arguing for what he terms 'layered identities'. Pearson here is proposing that individuals may have (or more accurately in his view should have) the capacity to be responsive to diverse cultural, emotional, ethical, pragmatic, economic, aesthetic and other affiliations across society, as well as within particular ethnic or cultural contexts. This framing allows Pearson to argue that cultural distinctiveness and integration, particularly through education and economically productive activity, ${ }^{2}$ are not mutually exclusive. Indeed, in Pearson's view, some form of integration is essential to the maintenance of viable distinctiveness - that is, productive livelihoods are necessary for the maintenance of Indigenous 'culture'. This echoes a point made somewhat controversially a decade ago by Pearson's colleague Richard Ah Mat (2003), who proposed that modernisation is essential to Indigenous cultural survival.

The concept of 'layered identities' does usefully challenge essentialised understandings of what it is to be authentically Indigenous. However, it does not incorporate the interpenetration of systems of meanings and practices, recursiveness, and transculturation encompassed by the sociological understandings of hybridity sketched in above. Consequently, it neither defines nor problematizes the characteristics of the Indigenous 'culture' which is to be maintained. What Pearson has called 'layered' identities might be more appropriately and accurately described as 'contextual' ones (Peterson, N. pers. comm.), or perhaps the results of the strategic bricolage of elements drawn from disparate domains (see Cowlishaw 2012: 400-5).

\section{Challenges of non-essentialised Indigenous identities}

History and social process can never be understood in terms of a unidirectional and predictable flow directed by those in power, as Levine (2001) demonstrates in relation to the early precursors to modernity itself; rather (like a large river) they involve crosscurrents, back eddies, and quiet stretches out of the main stream which can allow for a variety of life forms to flourish (Martin and Finlayson 2012). I have argued here that while Indigenous people may be strategically engaged with modernity, they are also creating a wide variety of responses to and manifestations of it, in the eddies and backwaters of the mainstream as well as within it. What can Indigenous people themselves, and those of us who are non-Indigenous specialists working in Indigenous affairs generally and in the native title arena in particular, glean from these arguments? 
I would suggest it is that there is a false dichotomy — indeed Cowlishaw (2012) refers to it as an absurdity - in much public discourse concerning on the one hand Indigenous identities ostensibly solely rooted in tradition and the past, and on the other those which derive their content and form through embracing elements of modernity. Such a dichotomy is implied not only in the native title practice of many anthropologists, lawyers and other specialists but also amongst many Indigenous people themselves. While I concentrate my discussion here largely on the native title arena, I would suggest that the implications of these arguments go well beyond native title itself, to core issues at the heart of Indigenous people's engagements with the wider Australian society and state, and of anthropological praxis concerned with that engagement.

Weiner (2011: 264) observes that the recognition by various private, government and statutory entities of Aboriginal identities, values and practices which are thoroughly contemporary and cannot be traced back to pre-sovereignty traditions - that is, can be seen as having adopted elements of modernity - may cause difficulties for subsequent generations of native title holders. I would agree with this observation to the extent that because the construction of native title by Australian law as having its origins in ongoing observance of the laws and customs from which it derives, a determination of native title is always vulnerable to subsequent challenge (for example, by a hostile resource developer or government) that traditional laws and customs are no longer practised by the group concerned. Nonetheless, in my view there are even greater risks for Indigenous people in acquiescing in and contributing to essentialised constructions of their identities and aspirations, for doing so risks both the pitfalls of cultural isolationism and the benefits of strategic engagement with modernity. For Indigenous people, it seems to me, there is a challenge to avoid what Robins (2003: 282) terms 'essentialism from below', ${ }^{3}$ which he argues can end up mirroring the romanticism and essentialism of post-development conceptions of Indigenous identity and the traditional/modern dichotomy. Equally, for the lawyers, anthropologists and others who work with Indigenous people in their native title claims and, particularly importantly, in the post-determination implementation stages and in the development arena more generally, the challenge is to accept the significance, reality and complexity of contemporary Indigenous identities. Like that of Koiki Mabo himself, these are best understood as thoroughly modern identities established as Indigenous people variously 
and strategically embrace, reject, but also transform elements of modernity drawn from the broader Australian (and global) society in which they are perforce enmeshed. Thus, it has been argued here that anthropologists working in native title in particular have largely been confined, but have also to some extent confined themselves, to matters related to the proof of native title, in a process I have referred to as a "stateresourced and mandated project of traditionalism" (Martin et al. 2011: 6).

Comparatively little anthropological attention, practical or theoretical, has been paid to the considerable entailments of the post-determination phase of native title, or to those of ILUAs and other agreements - let alone to the broader development issues for Indigenous people beyond those arising from native title claims. In our publication, we argued for a 'mirror image' anthropology, which could move beyond the traditionalist framing of native title law with its requirement to reconstruct the Indigenous present in terms of its putative past, to also working collaboratively with Indigenous people to develop understandings of their contemporary circumstances, and strategies to transform those circumstances - an applied anthropology of 'looking forward' rather than 'looking back'.

This would be a far more open-ended and outcomes-directed anthropology than that required for the proof of native title. For example, this latter form of anthropology is required to focus on such matters as the identity and continuity since sovereignty of the particular 'normative society' as native title law constructs it. However, a key concern for anthropology in the wider arena of native title practice (such as in agreementmaking) would be to develop an appropriate analysis of the characteristics of the relevant contemporary polity, and its implications for post-determination governance institutions. Thus, we argued, where anthropology directed to establishing native title typically elides diversity of perspectives, contested identities, and competition and conflict, post-determination anthropological practice, like that concerned with development issues more generally, would have to give close attention to such issues. This broader anthropology would therefore need to be explicitly concerned with such contemporary processes as Indigenous engagement with the wider society, development, and transformation, as well as with cultural continuities, and also actively and consciously be involved in socio-cultural change, not only in observing, analysing and critiquing it. The ethical entailments of such forms of practice are complex, and 
must be carefully considered in each case — but so too, I suggest, are those of unreflexive 'traditionalist' anthropological practice.

For Indigenous people themselves, I suggest, the necessary entailments of such transformations are not only the kinds of 'human capital' development to which government policies, and aspects of agreements, are directed (training, education and the like), significant though these may be. They also necessarily include potentially profound personal and collective ontological shifts, including new repertoires upon which to draw for reflexive self-awareness (Altman and Hinkson 2010: 189-191). But, I would suggest, change and transformation are intrinsic to the contemporary human condition, including for Australian Indigenous people. This is the case whether they live in urban, rural, or remote regions - and irrespective of any specific intentions, actions and interventions of the state.

I use the term 'interventions' deliberately here, because since its inception in 2007 what has been termed the 'Northern Territory intervention' has aroused a bitter national debate, dividing anthropologists in particular as well as Indigenous people themselves. This is an important debate, and there are good reasons to critically evaluate the political motivations for this 'Intervention' by government, the mechanisms which have progressively been rolled out to implement it, and its immediate and longer-term consequences as well as those of its successor policy framework (e.g. contributors in Altman and Hinkson 2007; Lattas and Morris 2010). However, since Indigenous lifeworlds are inextricably interlinked with the wider society, even in the most isolated of locales, it is my view that the issue is not intervention as such, because all social forms drawn from the wider society are interventions of one sort or another into Indigenous lives, whether imposed by the state or otherwise incorporated (Merlan 1998; Martin 2003). Even the most ostensibly benign government policy frameworks, such as those involving the recognition of various forms of Indigenous rights and interests, constitute interventions with often unintentional and sometimes negative consequences. Neither is transformation (so often the focus of traditionalists whether Indigenous or otherwise) necessarily an indication that Indigenous distinctiveness is at risk of being lost. Rather, the issue is whether, how, and to what degree Indigenous people themselves can have meaningful control over the nature and direction of change. I can see no justification whatsoever for anthropologists and other specialists to continue to 
focus on traditionalism as the primary mechanism through which they should assist in the maintenance of distinctive Indigenous identities, world views and domains of practices, whether in the native title arena or beyond it.

The arguments outlined in this paper would suggest that the ontological shifts accompanying economic, social and cultural transformations do not necessarily involve unidirectional morphing into a single mode of modernity and that diverse or perhaps even competing ontologies can coexist within 'hybrid' identities'. Perhaps, in the context of the personal and group identity options offered by the Australian native title system, and by wider development possibilities, anthropologists and lawyers should aim for 'hybrid' forms of practice in which both possibilities, traditionalist and modernist, are encompassed, with all their inherent contradictions as well as mutual entailments. This would be an undertaking which more fully reflected the legacy of Eddie Koiki Mabo's life.

\section{Acknowledgements}

My thanks go to members of the audiences of seminars and workshops for feedback on my earlier thinking around certain of the issues canvassed in this paper, and to colleagues who have commented on drafts. I owe a particular debt of gratitude to the Indigenous individuals who heard or read earlier versions of the presentation, and their generous reception of its arguments.

\section{References}

Aboriginal and Torres Strait Islander Social Justice Commissioner. 2011. Native Title Report 2011. Sydney: Australian Human Rights Commission.

Ah Mat, R. 2003. The moral case for Indigenous capitalism: Address to Native Title on the ground, AIATSIS Native Title Conference, Alice Springs, 5 June 2003. $<$ http://www.aiatsis.gov.au/ntru/nativetitleconference/conf2003/papers/ahmat.pdf >, accessed 29 April 2013.

Altman, J. C. 2001. Sustainable development options on Aboriginal land: The hybrid economy in the $21^{\text {st }}$ Century, CAEPR Discussion Paper No. 226. Canberra: Centre for Aboriginal Economic Policy Research, The Australian National University. 
Altman, J. C. 2005. Development options on Aboriginal land: Sustainable Indigenous hybrid economies in the twenty-first century. In L. Taylor, G. Ward, G.

Henderson, R. Davis, L. Wallis (eds.) The Power of Knowledge, the Resonance of Tradition, pp. 34-38. Canberra: Aboriginal Studies Press.

Altman, J. C. 2009. The hybrid economy and anthropological engagement with policy discourse: A brief reflection, The Australian Journal of Anthropology 20(3): 31829.

Altman, J. C, G. J. Buchanan, L. Larsen. 2007. The environmental significance of the Indigenous estate: Natural resource management as economic development in remote Australia. CAEPR Discussion Paper No. 286. Canberra: Centre for Aboriginal Economic Policy Research, The Australian National University.

Altman, J., M. Hinkson (eds). 2007. Coercive reconciliation: Stabilise, normalise, exit Aboriginal Australia. Melbourne: Arena Publications.

Altman, J., M. Hinkson. 2010. Very risky business: the quest to normalize remote Aboriginal Australia. In G. Marston, J. Moss, J. Quiggin (eds.) Risk, Responsibility and the Welfare State pp. 185-211. Melbourne: Melbourne University Press.

Austin-Broos, D. 2011. A Different Inequality: The Politics of Debate About Remote Indigenous Australia. Sydney: Allen and Unwin.

Bird-David, N. 1992. Beyond 'The hunting and gathering mode of subsistence': Culture-sensitive observations on the Nayaka and other modern hunter-gatherers. Man 27(1): 19-44.

Comaroff, J., J. L. Comaroff. 1997. Postcolonial Politics and Discourses of Democracy in Southern Africa: An Anthropological Reflection on African Political Modernities. Journal of Anthropological Research 53(2): 123-146.

Commonwealth of Australia. 1997. Native Title Amendment Bill 1997, Explanatory Memorandum.

Cowlishaw, G. 2012. Culture and the absurd: the means and meanings of Aboriginal identity in the time of cultural revivalism. Journal of the Royal Anthropological Society (n.s.) 18(2): 397-417.

Deutsch, J-G., P. Probst, H. Schmidt (eds) 2002. Perspectives on African Modernities. London: James Currey. 
Eisenstadt, S. N. 2000. Multiple modernities. Daedalus 1291: 1-29.

Folds, R. 2001. Crossed Purposes. The Pintupi and Australia's Indigenous Policy. Sydney: UNSW Press.

Friedman, J. 1999. Indigenous Struggles and The Discreet Charm of the Bourgeoisie. The Australian Journal of Anthropology 10(1): 1-14.

Godden, L., S. Dorsett 1999. The contractual status of Indigenous Land Use Agreements. In L. Strelein (ed.) Land, Rights, Laws: Issues of Native Title 2(1). Canberra: Native Title Research Unit, Australian Institute of Aboriginal and Torres Strait Islander Studies.

Goody, J. 2004. Capitalism and Modernity: The Great Debate. Cambridge, U.K. and Malden MA: Polity Press.

Gutiérrez, K.D., P. Baquedano-López, C. Tejeda. 1999 Rethinking diversity: Hybridity and hybrid language practices in the third space. Mind, Culture, and Activity 6(4): 286-303.

Hannerz, U. 2002 [1996]. Transnational Connections: Culture, People, Places. London: Routledge

Hay, C. 2004. The normalizing role of rationalist assumptions in the institutional embedding of neoliberalism. Economy and Society 33(4): 500-527

Hobsbawm, E., T. Ranger. 1983. The Invention of Tradition. Cambridge and New York: Cambridge University Press.

Hughes, H. 2005. Native Title's disasters, Letter to the Editor. Quadrant Magazine. July-August 2005.

Hughes, H. 2007. Lands of Shame: Aboriginal and Torres Strait Islander 'Homelands' in Transition. St Leonards: Centre for Independent Studies.

Hughes, H., J. Warin. 2005. A New Deal for Aborigines and Torres Strait Islanders in Remote Communities, Issue Analysis 54, Centre for Independent Studies, St Leonards, NSW. <http://www.cis.org.au>.

Johns, G. 2007. Making Land Rights Work. Melbourne: Bennelong Society.

Johns, G. 2008 The Northern Territory intervention in Aboriginal affairs: Wicked problem or wicked policy? Agenda 15(2): 65-84.

$<$ http://epress.anu.edu.au/agenda/015/02/pdf/whole.pdf>, accessed 29 April 2013. 
Johns, G. 2012 [2001]. The poverty of Aboriginal self-determination. In G. Johns (ed.) Waking up to Dreamtime: the Illusion of Aboriginal Self Determination, pp. 1534. Quadrant Online and Gary Johns.

$<$ http://www.quadrant.org.au/blogs/bennelong-papers/2012/02/waking-up-todreamtime-ebook>, accessed 29 April 2013.

Lattas, A., B. Morris. 2010. The Politics of Suffering and the Politics of Anthropology. In J. Altman, M. Hinkson (eds.) Culture Crisis: Anthropology and Politics in Aboriginal Australia, pp. 61-88. Sydney: UNSW Press.

Levine, D. 2001. At the dawn of modernity: Biology, culture and material life in Europe after the year 1000. Berkeley: University of California Press.

Loos, N., K. Mabo. 1996. Edward Koiki Mabo: His life and struggle for land rights. St Lucia: University of Queensland Press.

Mabo, G. n.d. Eddie Mabo.

$<$ http://hsc.csu.edu.au/ab_studies/rights/global/social_justice_global/sjwelcome.re sponse.front.htm>, accessed 15 January 2013.

Martin, D. F. 2001. Is welfare dependency “welfare poison”? An assessment of Noel Pearson's proposals for Aboriginal welfare reform. CAEPR Discussion Paper No. 213. Canberra: Centre for Aboriginal Economic Policy Research, The Australian National University.

Martin, D. F. 2003. Rethinking the design of Indigenous organisations: the need for strategic engagement, CAEPR Discussion Paper No. 248. Canberra: Centre for Aboriginal Economic Policy Research, The Australian National University.

Martin, D. F. 2009. The governance of agreements between Aboriginal people and resource developers: Principles for sustainability. In J.C. Altman, D.F. Martin (eds.) Power, Culture, Economy: Indigenous Australians and Mining, pp. 99-126. CAEPR Research Monograph No. 30. Canberra: ANU E Press.

Martin, D. F. 2011a. Policy alchemy and the magical transformation of Aboriginal society. In Y. Musharbash, M. Barber (eds.) Ethnography and the Production of Anthropological Knowledge: Essays in Honour of Nicolas Peterson, pp. 201-15. Canberra: ANU E-Press.

Martin, D. F. 2011b. Alternative constructions of Aboriginal identities in Australia's Native Title Act, and their implications for native title anthropology, paper 
presented in the session Dichotomous identities: Indigenous people and variously racialised others, joint conference of the International Union of Anthropological and Ethnological Sciences, the Australian Anthropological Society, and the Association of Social Anthropologists of Aotearoa/New Zealand. University of Western Australia, Perth, July 2011.

Martin, D. F. 2012. Alternative Constructions of Indigenous Identities in Australia's Native Title Act. In T. Bauman, L. Glick (eds.) The Limits of Change: Mabo and Native Title 20 Years On, pp. 353-362. Canberra: AIATSIS Research Publications.

Martin, D. F., J. D. Finlayson 2012. Regulating difference: Aborigines in the settler state. In P. Beilharz, T. Hogan (eds.) Sociology - Antipodean Perspectives, pp. 424-9. Melbourne: Oxford University Press.

Martin, D. F., T. Bauman, J. Neale. 2011. Challenges for Australian native title anthropology: Practice beyond the proof of connection. AIATSIS Research Discussion Paper No. 29. Canberra: Australian Institute of Aboriginal and Torres Strait Islander Studies.

Merlan, F. 1998. Caging the rainbow: Place, politics and agency in a north Australian town. Honolulu: University of Hawaii Press.

National Native Title Tribunal. 2012. National Report: Native Title, February 2012, $<$ http://www.nntt.gov.au/news-andcommunications/public\%20notifications/documents/2012\%20notifications/march/ si2012_004\%20clean\%20copy\%20ag60459.pdf>, accessed 29 April 2013.

National Native Title Tribunal. n.d. What is an Indigenous land use agreement? online fact sheet. $<$ http://www.nntt.gov.au/News-andCommunications/Publications/Documents/Brochures/ILUA\%20web\%20version.p df $>$, accessed 15 January 2013.

Pearson, N. 2006. Layered identities and peace, speech delivered at The Earth Dialogue, Brisbane Festival, 23 July 2006. Cairns: Cape York Institute.

Ritter, D. 2009. Contesting Native Title From Controversy to Consensus in the Struggle over Indigenous Land Rights. Sydney: Allen and Unwin.

Robins, S. 2003. Whose modernity? Indigenous modernities and land claims after Apartheid. Development and Change 34(2): 265-286. 
Rosaldo, R. 1995. Foreword. In N. G. Canclini (ed.) Hybrid cultures: Strategies for entering and leaving modernity, pp. xi-xvii. Translated by C. Chiapperi, S. López. Mineapolis: University of Minnesota.

Sachsenmaier, D., J. Riedel. 2002. Reflections on Multiple Modernities: European, Chinese, and other Interpretations. Leiden: Brill.

Sahlins M. 1999a. Two or three things I know about culture. Journal of the Royal Anthropological Institute 5(3): 399-421.

Sahlins, M. 1999b. What is Anthropological Enlightenment? Some Lessons of the Twentieth Century. Annual Review of Anthropology 28: i-xxiii.

Schmidt, V.H. 2006. Multiple Modernities or Varieties of Modernity? Current Sociology 54(1): 77-97.

Sen, A. 2006. Identity and violence. New York: W. W. Norton and Company.

Smith, D. E. 1998. Indigenous land use agreements: The opportunities, challenges and policy implications of the amended Native Title Act. CAEPR Discussion Paper No. 163. Canberra: Centre for Aboriginal Economic Policy Research, The Australian National University.

Strelein, L. 2009. Compromised jurisprudence: Native title cases since Mabo (2nd edn). Canberra: Aboriginal Studies Press.

Sutton, P. 2003. Native Title in Australia: An Ethnographic Perspective. Cambridge: Cambridge University Press.

Taylor, J. 2009. Social engineering and Indigenous settlement: Policy and demography in remote Australia, Australian Aboriginal Studies 1: 4-15.

Vásquez, M. A., M. F. Marquardt 2003. Globalizing the sacred: religion across the Americas. Piscataway, NJ: Rutgers University Press.

Weiner, J. 2011. Conflict in the statutory elicitation of Aboriginal culture in Australia, Anthropological Forum 21(3): 257-67.

\section{Notes}

The genesis of this paper lies largely in my work as a consulting anthropologist in the native title arena and in Indigenous development issues. Over the course of presenting a number of professional development workshops for anthropologists from 2007, I developed the outline of an account of 
native title anthropology as an intrinsically essentialist and traditionalist enterprise, and contrasted it with the challenges for an anthropology of Indigenous development, including the limited version of development available through the agreement-making provisions of the NTA. This work culminated in a jointly authored paper published focused on anthropological practice in the native title arena (Martin et al. 2011). Reflecting on this work in progress, it became clear to me that at its heart was a matter to which I had failed to give attention but which required it - the differing constructions of Indigenous identity implicit in different sections of the Native Title Act, and in the alternative (albeit related) forms of anthropological practice in proof of native title and in Indigenous development. These evolving ideas were first presented in a short paper in a session entitled 'Dichotomous Identities' at a 2011 conference co-hosted by the Australian Anthropological Society (Martin $2011 \mathrm{~b}$ ), and were also outlined in a brief contribution to a volume published by the Australian Institute of Aboriginal and Torres Strait Islander Studies to commemorate the $20^{\text {th }}$ anniversary of the landmark Australian High Court's Mabo decision (Martin 2012). These ideas were further developed over the course of a number of seminars and presentations in 2012 - in April at the University of Adelaide's Anthropology department; at a keynote address I presented at a June national native title symposium in Perth organised by the Centre for Native Title Anthropology at the Australian National University; and at a seminar in August at the Centre for Aboriginal Economic Policy Research at the Australian National University. The current paper is a substantially updated and revised account of my cumulative thinking on these issues for the purposes outlined at the beginning of the paper - anthropologists' engagement with the native title arena, and their dialogue about these issues with Indigenous people themselves.

2 However, Pearson has largely confined his discussions of productive activity to formal engagement with what he calls the 'real economy', particularly through wage labour. He has given little attention to other elements of 'hybrid' economies (Altman 2001, 2005), such as those based on the provision of environmental services, carbon trading, and the like.

3 In certain respects, what Robins terms 'essentialism from below' can be seen as sharing elements of Cowlishaw's (2012) analysis of 'cultural revivalism' in the construction of contemporary

Aboriginal identities. 